Review

\title{
Cell Therapy Clinical Trials for Stress Urinary Incontinence: Current Status and Perspectives
}

\author{
Isabel María Aragón, Bernardo Herrera Imbroda* and María Fernanda Lara*凶 \\ Department of Urology, Virgen de la Victoria University Hospital, Campus Universitario de Teatinos, Málaga, Spain. \\ *These two authors contributed equally to this work. \\ $\triangle$ Corresponding author: María F. Lara, Urology Unit Research, Virgen de la Victoria University Hospital, Campus Universitario de Teatinos s/n, 29010 \\ Malaga, Spain. Tel. +34 951032647; Fax +34 951440263. E-mail: mf.lara@fimabis.org. \\ () Ivyspring International Publisher. This is an open access article distributed under the terms of the Creative Commons Attribution (CC BY-NC) license \\ (https://creativecommons.org/licenses/by-nc/4.0/). See http://ivyspring.com/terms for full terms and conditions.
}

Received: 2017.07.28; Accepted: 2017.11.22; Published: 2018.01.01

\begin{abstract}
Stress urinary incontinence (SUI) affects 200 million people worldwide. Standard therapies often provide symptomatic relief, but without targeting the underlying etiology, and show tremendous patient-to-patient variability, limited success and complications associated with the procedures. We review in this article the latest clinical trials performed to treat SUI using cell-based therapies. These therapies, despite typically including only a small number of patients and short term evaluation of results, have proven to be feasible and safe. However, there is not yet a consensus for the best cell source to be used to treat SUI and not all patients may be suitable for these therapies. Therefore, more clinical trials should be promoted recruiting large number of patients and evaluating long term results.
\end{abstract}

Key words: Clinical trial, Cell therapy, Stress Urinary incontinence, Stem cells

\section{Introduction}

Urinary incontinence (UI) is an extremely common urological disorder that affects more than 200 million people worldwide [1]. Approximately, 17 million people suffer from this condition in the United States [2] with an annual direct cost estimated at more than $\$ 16$ billion [3]. Based on the International Continence Society there are three UI subtypes: urgency UI (UUI), stress UI (SUI), and mixed UI (MUI). SUI, defined as the involuntary leakage of urine in the absence of a detrusor contraction, generally due to the weakness of the urethral sphincter and pelvic floor [4], has been reported as the most common type of UI [3]. SUI occurs three times more often in women than in men [5]. The prevalence of SUI increases with age. For women, both pregnancy and vaginal delivery are risk factors for urinary sphincter injury. In men, SUI is also a common problem caused by injury to the neurovascular bundles and fasciae during radical prostatectomy [6]. Smoking, obesity and constipation contribute to SUI as well [7]. The severity of SUI influences the quality of life and medical treatment decisions [8]. Today, several SUI non-surgical and surgical treatment options are available. Mild-moderate SUI can be treated with pelvic floor muscle training, biofeedback training and/or electrical stimulation. Pharmacologic therapy for SUI such as Duloxetine hydrochloride, a selective reuptake inhibitor of serotonin and norepinephrine, was approved by the regulatory agency in the European Union in 2004, while it failed approval by the Food and Drug Administration in the United States due to security concerns [9]. Other pharmacologic treatments like alpha1-adrenoceptor agonists are being abandoned due to side effects [10]. For severe SUI, surgical interventions have been the most recommended medical treatment option. Urethral bulking agents including polytetrafluoroethylene, silicone, bovine collagen, carbon beads and autologous ear chondrocytes are the least invasive surgical intervention; however, its disadvantages include lower cure rate and complications, such as urinary tract infection, chronic inflammatory reactions, severe voiding dys- 
function, pulmonary embolism and abscess formation [11-13]. Other surgical treatments for SUI with better long-term success rates are the implantation of artificial urinary sphincter and the use of sling systems, although they also present post-operative complications [14-17]. In this context, the search and development of less invasive alternatives therapies as treatment for SUI continues to be a major need.

The use of stem cells in the field of regenerative medicine has emerged in the last years due to their capacity to restore and maintain normal function via direct effects on injured or dysfunctional tissues [18]. Stem cells are defined by three important characteristics: the ability to self-renew, to form clonal populations and to differentiate into different cell types. Stem cells may also show therapeutic effects by the secretion of a variety of bioactive factors (e.g. anti-apoptotic, neovascularization, etc.) that may have effects on innate tissues [18-19]. Stem cells can be divided in embryonic and adult stem cells. Embryonic stem cells are pluripotent and can differentiate into all types of tissue. Conversely, adult stem cells are multipotent and have been isolated from different tissues and organs, including bone marrow, peripheral blood, skeletal muscle, adipose tissue, skin and other sources. To date, the use of embryonic stem cells in clinical trials is limited due to cell proliferation control problems and ethical considerations [20]. In contrast, adult stem cells have no significant ethical issues related to their use.

Over the past decade, the advancement in tissue engineering and regenerative medicine research fields has allowed generation of promising results for treatment of SUI. Stem cell treatment has been tested in animal models and clinical trials demonstrating their potential to restore the urethral sphincter function [18, 21-27]. In the present review, we summarize the most relevant clinical trial with stem cells for SUI.

\section{Adult stem cells use in clinical trial for SUI treatment}

Regenerative medicine has become a popular research field in the search for novel therapies for SUI. Numerous studies have demonstrated in animals the efficacy of stem cells derived from skeletal muscle, adipose tissue, bone marrow and urine for the treatment of SUI [28-29]. Furthermore, clinical trials have been published in the last years using different source of adult stem cells [29].

\section{Muscle derived stem cell (MDSCs) therapy}

MDSC-based cell therapy has emerged in the last years as a promising approach for SUI patients [30]. The etiology of SUI includes the urethral sphincter muscle deficiency/damage; therefore, the use of MDSCs could improve the sphincter function. MDSCs have been considered as a precursor of the satellite cell, which possess a high regeneration capacity and are able to differentiate into other mesodermal cell types including the myogenic, endothelial, adipogenic, osteogenic, etc cell types. MDSCs can be easily obtained from skeletal muscle biopsies under local anesthesia. These cells, isolated from autologous biopsies, need to be expanded in vitro prior to the final injection into the urethral sphincter [31]. To date, several studies published have demonstrated an improvement in the sphincter function after the injection of intraurethral MDSCs in SUI animal models [32-33]. MDSCs isolated from the gastrocnemius muscle of normal adult female rats triggered a significant increase in the leak point pressure (LPP) at 4 and 6 weeks after urethral injection in rat models with sphincter deficiency $[32,34]$. Tissue staining using muscle-specific markers showed MDSCs potential to differentiate into muscle lineage cells that may repair the damaged sphincter muscle in SUI patients [32,34]. Moreover, an increase in urethral pressure profile and the formation of new muscle fibers was observed after the injection of MDSCs in the urinary sphincter of a porcine model [35]. The results observed in preclinical models opened the door to carry out clinical trials to determine the efficacy of MDSCs transplantation to treat SUI. In the present article, ten clinical trials have been reviewed using MDSCs or myoblasts with fibroblasts (Table 1). Eight of these clinical trials included only female patients and two trials comprised male patients (Fig. $1)$.

The first MDSCs therapy trial was reported in 2008 by Carr and colleagues. They included eight SUI female patients who had no improvement in symptoms for at least 12 months and failed prior non-invasive treatments. MDSCs were isolated from the thigh and $18-22 \times 10^{6}$ cells were transurethrally injected. Based on clinical evaluation measured by pad weight, bladder diaries and quality of life tests, a significant improvement was observed 12 months after treatment in six out of eight SUI patients, reporting total continence in one patient [23]. The remaining two patients showed a reduction of incontinence episodes of approximately $50 \%$ based on pad weight. In 2013, the same research group published a follow-up expanded study including 38 women with SUI which were treated with low doses $\left(1,2,4,8\right.$ or $\left.16 \times 10^{6}\right)$ or high doses $\left(32,64\right.$ or $\left.128 \times 10^{6}\right)$ of autologous MDSCs derived from biopsies of their quadriceps femoris. A transvaginal ultrasound 
guidance to confirm that cells have been injected within the sphincter muscle was used in nine patients; however this guidance did not affect the outcomes. Moreover, 32 patients in this trial were retreated (20 with low cell dose and 12 with high cell doses) after three months of follow-up. Data from five patients were not included in the analysis because of withdrawal or loss of follow-up. Authors showed a $50 \%$ or greater reduction in pad weight and diary reported stress leaks, after cell therapy. This result was reached more frequently in patients with high cell dose injections than in patients treated with low cell doses (88.9\% vs $61.5 \% ; \quad 77.8 \%$ vs $53.3 \%$ respectively). Furthermore, a greater percentage of patients treated with a high cell dose compared to a low cell dose had zero to one leaks during three days at the 18 month follow-up ( $88.9 \%$ vs $33.3 \%$ ). A similar trend was reported for the mean incontinence impact questionnaire-short form (IIQ-7) score (38.5 \pm 4.4 vs $17.5 \pm 6.2, \mathrm{p}=0.02)$; however no differences in both dose groups were reported for the urogenital distress inventory-short form (UDI-6) score. These data suggest that high cell dose injection improves SUI symptoms more than a low cell dose [36].
A.

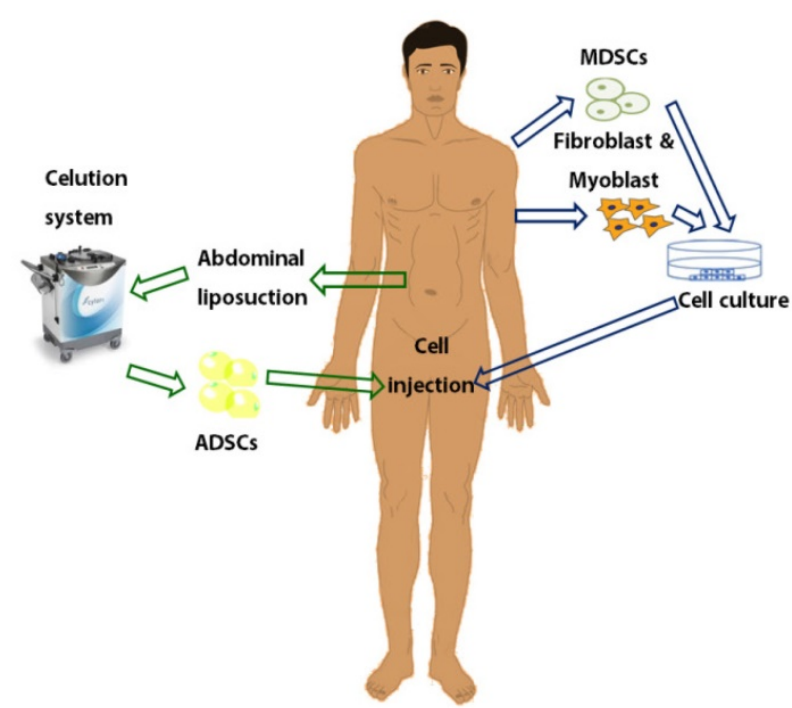

B.

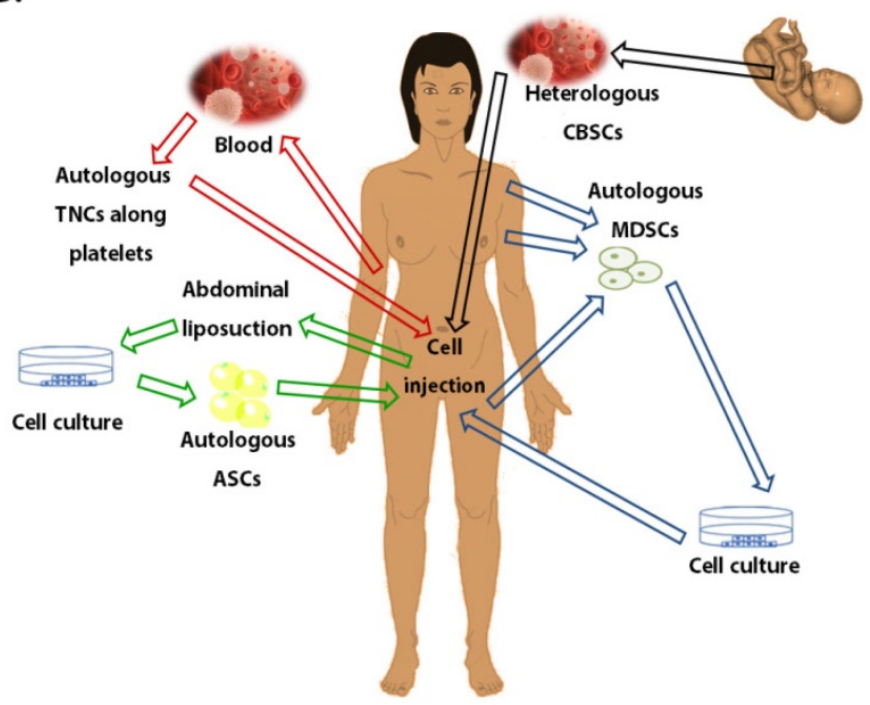

Figure 1. Schematic representation of the different tissue sources for stem cells used in clinical trials to treat stress urinary incontinence. A. Stem cells used in men patients. B. Stem cells used in female patients. Abbreviations: MDSCs, Muscle-derived stem cells; ASCs, Adipose stem cells; ADSCs, Adipose-derived stem cells; CBSCs, Cord Blood stem cells; TNCs, Total nucleated cells.

Table 1. Clinical trials using muscle derived stem cells for stress urinary incontinence.

\begin{tabular}{|c|c|c|c|c|c|c|c|c|c|c|}
\hline Cell used & $\begin{array}{l}\text { Patholo } \\
\text { gy } \\
\text { treated }\end{array}$ & Patients & Area of injection & $\begin{array}{l}\text { Follow-up } \\
\text { months }\end{array}$ & $\begin{array}{l}\text { Functional } \\
\text { Evaluatio } \\
\mathbf{n}\end{array}$ & $\begin{array}{l}\text { Functional } \\
\text { Outcomes at } \\
\text { final follow-up }\end{array}$ & $\begin{array}{l}\text { Clinical } \\
\text { Evaluation }\end{array}$ & $\begin{array}{l}\text { Clinical } \\
\text { Outcomes at final } \\
\text { follow-up }\end{array}$ & Adverse events & $\begin{array}{l}\text { Refer } \\
\text { ence }\end{array}$ \\
\hline $\begin{array}{l}\text { Autologous } \\
\text { MDSCs }\end{array}$ & SUI & 8 females & $\begin{array}{l}\text { Transurethral } \\
\text { (injection at 3, 6, 9, } \\
\text { and } 12 o^{\prime} \text { clock) }\end{array}$ & $1,3,6$ and 12 & $\mathrm{n} / \mathrm{a}$ & $\mathrm{n} / \mathrm{a}$ & $\begin{array}{l}\text { Pad weight/ } \\
\text { bladder } \\
\text { diaries/ QOL } \\
\text { measures. }\end{array}$ & $\begin{array}{l}1 / 8 \text { total } \\
\text { continence } \\
5 / 8 \text { significant } \\
\text { improvement } \\
2 / 8 \approx 50 \% \\
\text { incontinence } \\
\text { reduction }\end{array}$ & $\begin{array}{l}\text { No severe effects were } \\
\text { observed. }\end{array}$ & [23] \\
\hline $\begin{array}{l}\text { Autologous } \\
\text { fibroblast and } \\
\text { myoblast }\end{array}$ & $\begin{array}{l}\text { UI after } \\
\text { RP }\end{array}$ & 63 males & $\begin{array}{l}\text { Urethral } \\
\text { submucosa and } \\
\text { rhabdosphincter }\end{array}$ & 12 & $\begin{array}{l}\text { VLPP/ } \\
\text { MUCP/ } \\
\text { MBC/ } \\
\text { MUF/ } \\
\text { MDP/MR } \\
\text { U }\end{array}$ & $\begin{array}{l}\text {-VLPP increase } \\
\left(\approx 22 \mathrm{cmH}_{2} \mathrm{O}\right) \\
\text {-MUCP } \\
\text { increase }(\approx 17 \\
\left.\mathrm{cmH}_{2} \mathrm{O}\right) \\
-\mathrm{MBC}_{\text {increase }} \\
(\approx 26 \mathrm{ml}) \\
-\mathrm{MUF} \text { increase } \\
(\approx 2 \mathrm{ml} / \text { sec }) \\
-\mathrm{MDP} \mathrm{decrease} \\
\left(\approx 8 \mathrm{cmH} \mathrm{H}_{2} \mathrm{O}\right) \\
-\mathrm{MRU} \mathrm{decrease} \\
(\approx 37.5 \mathrm{ml})\end{array}$ & $\begin{array}{l}\text { 24-hour } \\
\text { voiding } \\
\text { diary /24-hour } \\
\text { pad test/ } \\
\text { incontinence } \\
\text { score/ QOL } \\
\text { score }\end{array}$ & $\begin{array}{l}\text { 24-hour voiding } \\
\text { diary/ pad test: } \\
41 / 63 \text { total } \\
\text { continence } \\
17 / 63 \\
\text { improvement } \\
5 / 63 \text { non } \\
\text { improvement. } \\
\text { Improvement } \\
\text { incontinence }(\approx 5) / \\
\text { QOL }(\approx 50) \text { score. . }\end{array}$ & $\begin{array}{l}\text { No severe postoperative } \\
\text { complications were } \\
\text { observed. }\end{array}$ & [42] \\
\hline $\begin{array}{l}\text { Autologous } \\
\text { MDSCs }\end{array}$ & SUI & 12 females & $\begin{array}{l}\text { Endourethral } \\
\text { (injection at } 3 \text { and } \\
9 \text { o'clock). }^{\prime}\end{array}$ & $\begin{array}{l}1,2,3,6 \text { and } \\
12\end{array}$ & $\begin{array}{l}\text { MUF/ } \\
\text { PVR }\end{array}$ & $\begin{array}{l}\text { MUF/PVR w/o } \\
\text { change }\end{array}$ & $\begin{array}{l}\text { CONTILIFE } \\
\text { questionnaire/ } \\
\text { pad test/ } \\
\text { bladder diary }\end{array}$ & $\begin{array}{l}3 / 12 \text { dry } \\
7 / 12 \text { wet } \\
\text { improvement/ no } \\
\text { voiding diary } \\
\text { improvement }\end{array}$ & $\begin{array}{l}\text { Episodes of UTI were } \\
\text { reported in three patients. }\end{array}$ & [21] \\
\hline
\end{tabular}




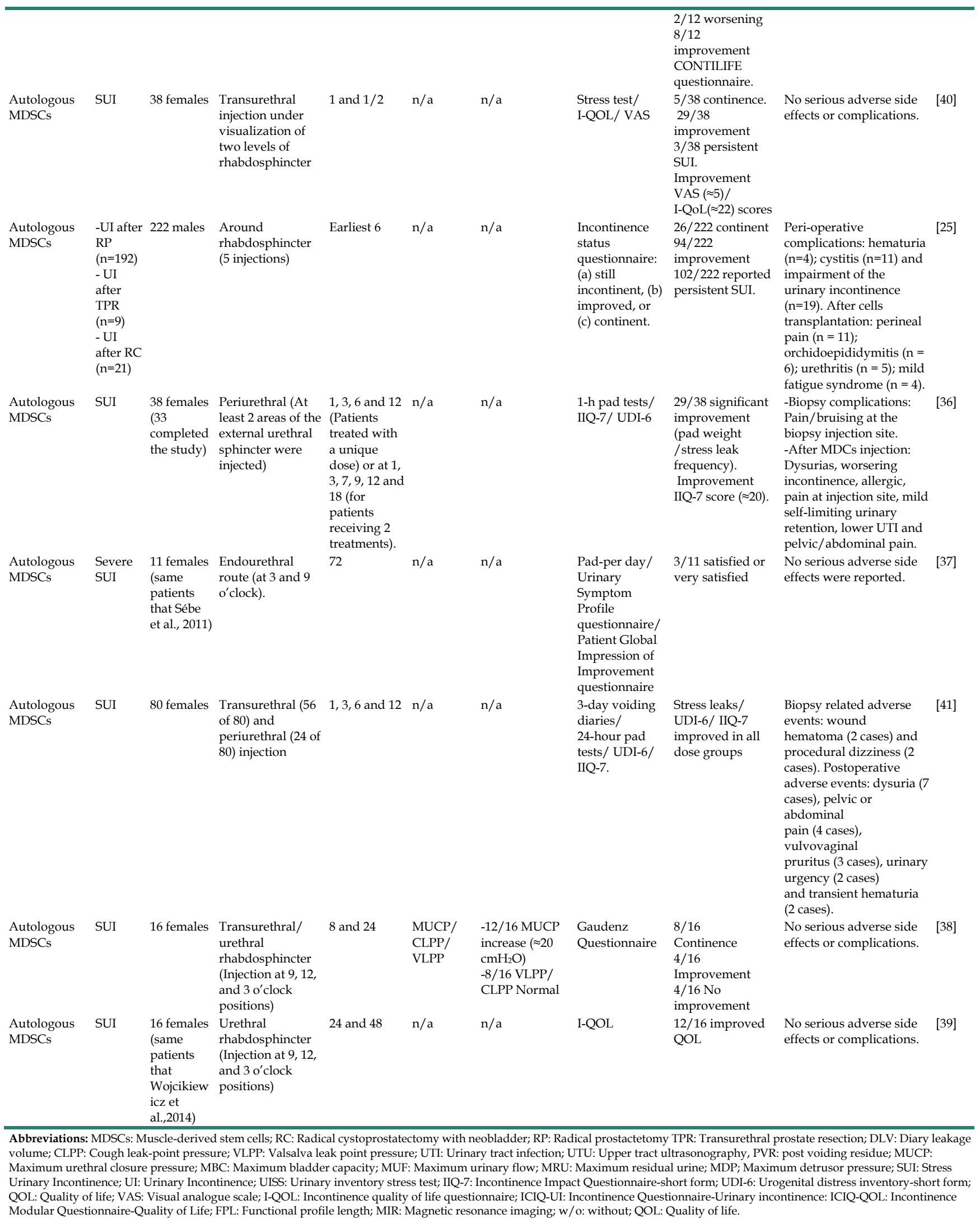


In 2011, Sebe et al. published a clinical and functional evaluation from 12 females with SUI (eight with severe SUI; two with moderate SUI; two with mild SUI) after MDSCs transplantation, which were isolated from a deltoid muscle biopsy [21]. These patients were divided in three groups of four patients, treating each group with $10 \times 10^{6}, 25 \times 10^{6}$, and $50 \times 10^{6}$ cells, respectively. Based on the pad test after 12 months, three patients were completely dry, seven patients had a significant reduction in the number of pads required but did not improve based on voiding diary and two patients showed worsening after the procedure. CONTILIFE questionnaire showed an increase in three patients who responded to treatment, as well as in patients who did not show an objective clinical response. Moreover, no patients improved based on maximum urine flow (MUF) and post-void residual volume (PVR) after 12 months of follow-up [21] (Table 1). In this clinical trial no correlation was observed between cell dose or SUI severity and response to treatment. Furthermore, a positive clinical effect was observed up to 72 months in three of these patients attending to pad-test per day and symptoms and quality of life questionnaires (QOL-q) [37]. In 2014, Wojcikiewicz et al. carried out a clinical trial on 16 female SUI patients, using 0.6-25×106 MDSCs from the deltoid muscle biopsy. Based on clinical parameters (Gaudenz questionnaire) and urodynamics parameters (cough leak-point pressure (CLPP); valsalva leak-point pressure (VLPP)) they observed at eight months of follow-up an improvement in $75 \%$ of SUI patients (50\% continence (group T); 25\% some improvement (group P) and 25\% no improvement (group N)). An increase in urodynamic parameters such as maximum urethral closure pressure (MUCP) was observed in patients previously framed in the group $\mathrm{T}$ and $\mathrm{P}$ (from 31 and 29.88 to 50.25 and $51.38 \mathrm{cmH} 2 \mathrm{O}$, respectively). The positive results observed in these patients were sustained up to 24 months [38]. A clinical assessment (incontinence QOL-q) demonstrated a beneficial effect of the MDSC therapy up to 48 months [39]. Long-term follow-up carried out by Cornu et al. and Wojcikiewicz et al. showed evidence of long durability results up to six years after MDSC cell injection [37, 39]; however, a large series of patients would be necessary to confirm these results and to determine when a retreatment is required. Blaganje et al. observed the most elevated improvement rates (91.9\%; 33 of 38 patients) based on incontinence QOL-q published to date using $1 \times 10^{6}-50 \times 10^{6}$ MDSCs in $2 \mathrm{ml}$, isolated from the biceps muscle; however, they presented only six weeks of follow-up data [40]. On the other hand, the largest cohort of SUI female patients was published in 2014 by Peters et al. and included 80 female who were divided in four MDSC dose groups $\left(10 \times 10^{6} ; 50 \times 10^{6} ; 100 \times 10^{6} ; 200 \times 10^{6}\right)$ isolated from biopsies of each patient's quadriceps femoris. Transurethral (56 of 80 patients) and periurethral (24 of 80) injection was also compared in this study, although similar stress leak and pad test results were observed in both approaches. All dose groups showed a significant reduction in the diary reported stress leaks, IIQ-7 and UDI-6 at 12 months; these results were observed within one to three months of cell therapy. After 12 months of follow-up they suggested a potential dose response for stress leaks, with a greater percentage of patients responsive to higher doses [41]. However, IIQ-7 and UDI-6 did not appear dose related.

Two trials carried out in SUI male patients showed moderate to good clinical efficacy using MDSC therapy (Table 1). Mitterberger et al. in 2008 included 63 male patients with SUI after radical prostatectomy (RP) [42]. They were treated with autologous fibroblasts $\left(38 \times 10^{6}\right)$ and myoblasts $\left(28 \times 10^{6}\right)$ obtained from skeletal muscle biopsies. After 12 months of follow-up a significant improvement in these patients were observed according to urodynamics (VLPP, MUCP, MUF maximum bladder capacity (MBC), maximum residual urine (MRU) and maximum detrusor pressure (MDP)) (Table 1). Furthermore, rhabdosphincter thickness (mean $2.2 \pm 0.4$ vs $3.3 \pm 0.4$ ) and contractility (mean $0.7 \pm 0.3$ vs $1.2 \pm 0.3$ ) were also significantly improved. Based on voiding diaries and the pad test, 58 out of 63 patients showed a significant clinical improvement $(90.4 \%$ of patients); however these promising results were not reconfirmed long-term [42]. These results are similar to the best results observed in a female clinical trial [40]; however the cells used in both trials are different. Moreover, only 1 month of follow-up was carried out by Blaganje et al [40]. Four years later, 222 male patients with SUI after RP, transurethral prostate resection or radical cystoprostatectomy with neobladder were treated with transurethral injections of autologous MDSCs $\left(100 \times 10^{6}\right.$ cells $)$ [25]. In this study after 6 months of follow-up 102 patients still reported incontinence, observing a beneficial effect in the remaining 119 patients according to the incontinence QOL-q. Moreover, in this study the authors characterized the transplanted cells by immunostaining for different skeletal muscle markers. A positive staining was observed for approximately a $50 \%$ of transplanted cells [25].

In conclusion, all clinical trials published in male and female SUI patients treated with MDSCs, myoblasts, and fibroblasts showed feasibility and safety of the cell therapy although non-severe complication were observed in some clinical trials 
(Table 1). Early clinical experiences suggest that autologous MDSCs injection therapy may be a promising treatment to restore urethral sphincter function; however, further clinical trials with large sample size and uniformity in the assessment, cell dose and incorporation of a placebo control group are necessary for these findings to be applied in the clinical practice in urology.

\section{Injection of adult stem cells others than MDSCs}

Even though MDSCs fulfill the conditions to regenerate striated muscle because they are known to be responsible for physiological muscle regeneration throughout life, they are in short supply, do not expand well ex vivo and protocols for prospective isolation of pure populations of human satellite cells are still under development [43]. Clinical trials mentioned utilized muscle biopsies harvested from healthy deltoid, biceps or the quadriceps femoris muscle [21, 23, 25, 36-42]. This method is problematic since it causes co-morbidity at the sites of cell harvest. To reduce the damage to the patient, small biopsies are collected, which required major expansion of the cells in vitro. This approach is thus associated with a risk of contaminations, and can result in physiological or functional changes and signs of replicative senescence of cells. For these reasons other clinical trials have used other sources of mesenchymal adult stem cells (MSCs) derived from embryonic mesoderm that can be easily and safely harvested in large numbers from several adult tissues such as adipose tissue, umbilical cord or peripheral blood and with minimal morbidity.

In culture, adipose derived stem cells (ADSCs) exhibited differentiation into myogenic cells when induced with specific factors [44-45]. Furthermore, cultured ADSCs promote angiogenesis by secreting hepatocyte growth factor and vascular endothelial growth factor [46]. Consequently, ADSCs has been evaluated as a cell therapy in murine models of SUI [26, 47-49]. In most cases a significant increase in the functional assessment (LPP) after ADSCs injection was reported. However, the muscle regenerative capacity or the in vivo mechanisms of these cell sources to achieve such results are not well defined [28]. Nonetheless, the experience in animal models of SUI with ADSCs, demonstrated the cell viability and the paracrine capacity of these cells at the injection site $[28,48,50]$.

Four clinical trials using adipose tissue cells to treat SUI have been reviewed (Table 2; Fig 1). Three of these trials were performed in male patients with SUI due to sphincter deficiency after RP [51-53]. All clinical trials performed in male patients have used
ADRCs (adipose-derived regenerative cells), i.e., a mixture of cells including adipose stem cells, and mature and progenitors cells, as well as characterized stromal fibroblastic cell populations obtained by liposuction from adipose tissue from the abdominal wall and isolating cells using the Celution System ${ }^{\mathrm{TM}}$ [54]. The advantage of this system is the short time required for ADRCs collection, reproducibility of the procedure and it is adequate for human transplantation. Due to the amount of cells obtained, a culture phase is not needed and therefore, the complete procedure of cell harvest and injection can be carried out in a single day surgical procedure [52]. All three cases followed the same protocol injecting ADRCs at a depth of $5 \mathrm{~mm}$ into the external urethral sphincter at 5 and 7 o'clock positions and subsequently, they injected $20 \mathrm{ml}$ of a formulation containing ADRCs and adipose tissue into the submucosal spaces at 4,6 and 8 o'clock to facilitate complete adjustment of the urethral mucosa by the bulking effect [51-52]. In the preliminary clinical study of Yamamoto et al., they included just three patients in the first attempt with a maximum follow up period of six months [51]. They reported an improvement of UI within a week after injection with a short period of deterioration afterwards and a progressive improvement thereafter up to six months after injection [51].The improvement in UI was shown by decreased leakage volume (from 122.3, 49.5 and $35.0 \mathrm{~g}$ to $50.5,11.5$ and $0 \mathrm{~g}$ respectively), decreased frequency, amount of incontinence and improved QOL. Both MUCP (from 40, 39 and $28 \mathrm{cmH}_{2} \mathrm{O}$ to 53, 45 and $40 \mathrm{cmH}_{2} \mathrm{O}$, respectively) and functional profile length (from 20, 15 and $14 \mathrm{~mm}$ to 24, 40 and $28 \mathrm{~mm}$, respectively) increased. Besides, magnetic resonance imaging (MRI) showed a bulking effect at the site of the injection at three months, suggesting a sustained presence of adipose tissue. Furthermore, enhanced ultrasonography showed a sequential increase in the blood flow during the entire follow-up period in to the area where ADRCs were injected. Besides, Yamamoto et al. performed MRI to patients and showed a bulking effect at the site of the injection that last 12 weeks. Two years later (2014) the same group extended the study to 11 patients with a follow-up period of 12 months. They reported similar results in eight patients out of 11, with a progressive improvement up to 12 months after a deterioration period one month after injection. In both studies the deterioration period is explained by the authors due to the absorption of the lactated Ringer's solution contained in the isolated ADRCs injected. Gotoh et al. showed a decrease of $59.8 \%$ in the leakage volume decreased in frequency and amount of incontinence and improved QOL with a total continence achieved 
in one patient. They showed that, the mean MUCP increased in $9 \mathrm{cmH}_{2} \mathrm{O}$ from baseline, the functional profile length increased $6 \mathrm{~mm}$ and PVR decreased in $4.5 \mathrm{ml}$ after treatment [52]. Moreover, authors suggested an angiogenesis effect based on an increased blood flow to the injected area shown by ultrasonography. In 2016, a third clinical trial Choi et al. used ADRCs to treat six men with persistent UI after RP. They showed similar results to previously described studies; however, only two patients went through the deterioration period described above. By 12 weeks after treatment, leakage volume as well as the subjective symptoms and QOL, were improved in all cases. MUCP increased even more than in previous studies by $19 \mathrm{cmH}_{2} \mathrm{O}$ from baseline and the MRI showed an increase in the urethral length. In any case, all clinical studies using ADRCs to treat SUI are preliminary and included only few patients. Indeed the largest study included only 11 patients and, taking into account the three studies published using ADRCs, only a total of 20 male patients have been treated with ADRCs. Moreover, Gotoh et al. published a follow up result of one year, while Yamamoto et al. and Choi et al. studies evaluated only up to six and three months respectively [51-53]. This group concluded that 17 male patients out of 20 responded positively to ADRCs therapy at six months.

On the other hand, one clinical trial using adipose stem cells (ASCs) derived from subcutaneous fat from the lower abdomen was performed in five women with pure SUI or predominantly stress MUI [55]. In this case, Kuismanen et al. did not use the Celution System and therefore they needed to expand the cells for at least three days in culture to obtain the adequate amount of cells to be injected. Besides, they mixed the ASCs with collagen which may increase the bulking effect and allow the cells to stay in place. They injected 2.4-4 $\mathrm{ml}$ of cell volume (number of cells varied from $2.5 \times 10^{6}$ to $8.5 \times 10^{6}$ ) $1.5 \mathrm{~cm}$ distal to the urethral neck at 3 and 9 o'clock positions and they added two additional injections of ASCs mixed with saline solution $2 \mathrm{~mm}$ distal to the first injection with the aim of injecting the cells into the urethral musculature [55]. At six months only one out of five patients treated shoed improved UI symptoms based on the cough test and at 1 year the test was negative for three patients that also improved the 24-h pad test; however only two were satisfied and did not wish further treatment for SUI [55]. There was subjective improvement in all five patients according to the QOL-q; however there were no changes in urodynamic parameters or the urine residual volume in any patients. These data suggest more of a bulking effect than a muscle regeneration effect. Furthermore, three of the patients were operated after one year of follow-up.

In conclusion, even though ASCs have proven to be safe, it is important to accurately define the type of patient that could benefit from this therapy and to use consistent cell isolation systems to guarantee a standard procedure as much as possible for each patient.

Furthermore, other non-adipose derived stem cells were used in two clinical trials that included SUI female patients (Table 2). Cord blood stem cells (CBSCs) can be extracted from human cord blood without harm, they can transform into other cell types and therefore are expected to be useful for the regeneration of periuretral nervous tissue, smooth muscle, striated muscle, urethral mucosa, submucosal connective tissue and various other tissues [56]. In rats, mononuclear cells from human umbilical cord blood have been evaluated as treatment for intrinsic sphincter deficiency. The short term (four weeks) effect showed an improved LPP in the experimental group $(91.75 \pm 18.99 \mathrm{mmHg}$ vs $65.02 \pm 22.09 \mathrm{mmHg}$; $\mathrm{p}=0.001$ ). Histological analysis showed a restored sphincter muscle with identification of the injected cells in the area of the injection. However, data at one month are not strong enough to support the use of CBSCs in clinical trials; however Lee et al. used CBSCs for the treatment of 39 SUI female patients after conservative or surgical treatment failed. They injected CBSCs in the 4 and 8 o'clock positions $\left(430 \pm 190 \times 10^{6}\right.$ cells per $\left.2 \mathrm{ml}\right)$ in the submucosal area of the proximal-urethra [56]. Patient satisfaction tests at 12 months after cell injection showed that 13 patients were completely satisfied with the treatment at that point, 13 patients improved and ten patients did not improve clinically. Urodynamic evaluation was also performed at three months in ten patients who had a MUCP $\leq 30 \mathrm{cmH}_{2} \mathrm{O}$ before treatment, and showed that the MUCP value almost doubled after cell injection.

Finally, autologous total nucleated cells (TNCs) along with platelets were evaluated for the treatment of SUI. Multipotent cells and endothelial progenitor cells (EPCs) can be obtained from peripheral blood in a minimally invasive method for production of autologous cells for use in cell therapies. Tissue repair depends on new blood vessels and capillary development that may need the cooperation of EPCs. In fact, angiogenesis is essential for muscle repair; endothelial cells stimulate myogenic cell growth and also stimulate to the differentiating myogenic cells to promote angiogenesis [56]. Platelet-rich plasma has been used in in vitro and in vivo studies to regenerate muscle healing [57]. This effect has been associated with the numerous growth factors (e.g fibroblast growth factors, vascular endothelial growth factors, 
etc.) produced by platelets. A clinical trial was carried using TNCs mixed with platelets in nine female patients with severe SUI who did not respond to conventional treatment [58]. Eight injections of $1 \mathrm{ml}(8$ $\mathrm{ml}$ in total) were performed at a depth of $5 \mathrm{~mm}$ into the rhabdosphincter. They observed a high clinical efficacy at three and six months after cell therapy, with eight patients reporting no leaks according to clinical (pad-test, cough test and QOL-q) tests. Urodynamics evaluation (post voiding residue; upper tract ultrasonography and uroflowmetry) showed that all parameters were normal in all patients at one, three and six months after cell therapy. However, one patient, previously diagnosed with intrinsic sphincter deficiency (ISD), did not returned at that point to normal continence completely, but did show an improvement based on the Incontinence Questionnaire-Urinary incontinence (ICIQ-UI), Incontinence Modular Questionnaire-Quality of Life (ICIQ-QOL) and pad-test. MUCP in this patient showed a significant increase from the baseline to 3 months after cell transplantation.

Table 2. Clinical trials carried out using non-muscle derivate stem cells for the treatment of SUI.

\begin{tabular}{|c|c|c|c|c|c|c|c|c|c|c|}
\hline Cells used & $\begin{array}{l}\text { Pathology } \\
\text { treated }\end{array}$ & Patients & Area of injection & $\begin{array}{l}\text { Follow up } \\
\text { months }\end{array}$ & $\begin{array}{l}\text { Functional } \\
\text { Evaluation }\end{array}$ & $\begin{array}{l}\text { Functional } \\
\text { outcomes } \\
\text { at final } \\
\text { follow-up }\end{array}$ & $\begin{array}{l}\text { Clinical } \\
\text { Evaluation }\end{array}$ & $\begin{array}{l}\text { Clinical } \\
\text { outcomes at } \\
\text { final } \\
\text { follow-up }\end{array}$ & $\begin{array}{l}\text { Adverse } \\
\text { events }\end{array}$ & Reference \\
\hline $\begin{array}{l}\text { Heterologo } \\
\text { us } \\
\text { CBSCs }\end{array}$ & SUI & $\begin{array}{l}39 \text { females } \\
\text { (only } 36 \\
\text { completed } \\
\text { follow-up) }\end{array}$ & $\begin{array}{l}\text { Submucosal area of the } \\
\text { proximal urethra ( } 4 \text { and } \\
8 \text { o'clock positions) }\end{array}$ & 1,3 and 12 & MUCP & $\begin{array}{l}-10 / 39 \\
\text { MUCP } \\
\text { increase } \\
(\approx 25 \\
\left.\mathrm{cmH}_{2} \mathrm{O}\right)\end{array}$ & $\begin{array}{l}\text { Patient } \\
\text { Satisfaction Test }\end{array}$ & $\begin{array}{l}\text { 13/36 total } \\
\text { continence } \\
13 / 36 \\
\text { improvement } \\
\text { 10/36 non } \\
\text { improvement }\end{array}$ & $\begin{array}{l}\text { Peri-operative } \\
\text { complications: } \\
\text { pain }(n=2) . \\
\text { Non } \\
\text { post-operative } \\
\text { complications } \\
\text { were } \\
\text { observed. }\end{array}$ & [33] \\
\hline $\begin{array}{l}\text { Autologou } \\
\text { s ADRCs }\end{array}$ & UI after RP & 3 males & $\begin{array}{l}\text { Periurethral injection: } \\
\text {-Rhabdosphincter ( } 5 \\
\text { and } 7 \text { o'clock positions) } \\
\text {-Submucosal space of } \\
\text { the membranous } \\
\text { urethra ( } 4,6 \text { and } 8 \\
\text { o'clock positions). }\end{array}$ & $\begin{array}{l}-1 / 2,1,2,3, \\
6 \text { (Clinical } \\
\text { Evaluation) } \\
-1 / 2,3 \text { and } \\
6 \\
\text { (Functional } \\
\text { Evaluation). }\end{array}$ & MUCP/FPL & $\begin{array}{l}\text {-MUCP } \\
\text { increase } \\
(6-13 \\
\left.\mathrm{cmH}_{2} \mathrm{O}\right) \\
\text {-FLP } \\
\text { increase } \\
(4-25 \mathrm{~mm})\end{array}$ & $\begin{array}{l}\text { 24-h pad test } \\
\text { /ICIQ-SF }\end{array}$ & $\begin{array}{l}3 / 3 \\
\text { Improvement }\end{array}$ & $\begin{array}{l}\text { No side effects } \\
\text { or } \\
\text { complications. }\end{array}$ & [51] \\
\hline $\begin{array}{l}\text { Autologou } \\
\text { s } \\
\text { TNCs/plat } \\
\text { elets }\end{array}$ & Severe SUI & 9 females & $\begin{array}{l}\text { Periurethral injection } \\
\text { (rhabdosphincter at } 1.5, \\
3,4.5,6 \text {, } \\
7.5,9,10.5 \text {, and } 12 \\
\text { O'clock positions) }\end{array}$ & 1,3 and 6 & $\begin{array}{l}\text { MUCP/UTU/ } \\
\text { UFL/PVR. }\end{array}$ & $\begin{array}{l}-\mathrm{UTU} / \\
\text { PVR/ UFL } \\
\text { normal } \\
-1 / 9 \\
\text { Increase } \\
\mathrm{MUCP} \\
\text { (from }<30 \\
\text { to } \geq 30 \mathrm{~cm} \\
\mathrm{H}_{2} \mathrm{O} \text { ) } \\
-8 / 9 \\
\text { MUCP n/a }\end{array}$ & $\begin{array}{l}1 \mathrm{hr} \text { pad tests/ } \\
\text { Cough test/ } \\
\text { ICIQ-UI/ } \\
\text { ICIQ-QOL }\end{array}$ & $\begin{array}{l}-9 / 9 \text { ICIQ-UI/ } \\
\text { ICIQ-QOL/ } \\
\text { pad test } \\
\text { improvement. } \\
-8 / 9 \text { Cough } \\
\text { test } \\
\text { improvement. }\end{array}$ & $\begin{array}{l}\text { No } \\
\text { complications }\end{array}$ & [58] \\
\hline $\begin{array}{l}\text { Autologou } \\
\text { s ASCs }\end{array}$ & SUI & 5 females & $\begin{array}{l}\text { Under mucosa }(1.5 \mathrm{~cm} \\
\text { distal from the urethral } \\
\text { neck at } 3 \text { and } 9 o^{\prime} \text { clock.) }\end{array}$ & 3,6 and 12 & MUCP/URV & $\begin{array}{l}\text { MUCP w/o } \\
\text { change }\end{array}$ & $\begin{array}{l}\text { 24-h pad test } \\
\text { /UISS/ UDI-6/ } \\
\text { IIQ-7/ VAS }\end{array}$ & $\begin{array}{l}3 / 5 \\
\text { Improvement }\end{array}$ & $\begin{array}{l}\text { Small } \\
\text { hematomas. } \\
\text { One patients } \\
\text { displayed } \\
\text { mild pollacis } \\
\text { and dysuria. }\end{array}$ & [55] \\
\hline $\begin{array}{l}\text { Autologou } \\
\text { s ADRCs }\end{array}$ & $\begin{array}{l}\text { SUI after } \\
\text { prostate } \\
\text { surgery }(n=9) \\
\text { SUI after } \\
\text { holmium laser } \\
\text { enucleation(n= } \\
\text { 2) }\end{array}$ & 11 males & $\begin{array}{l}\text { Periurethral injection: } \\
\text {-Rhabdosphincter ( } 5 \\
\text { and } 7 \text { o'clock positions) } \\
\text {-Submucosal space of } \\
\text { the membranous } \\
\text { urethra ( } 4,6 \text { and } 8 \\
\text { o'clock positions). }\end{array}$ & $\begin{array}{l}1 / 2,1,3,6,9 \\
\text { and } 12\end{array}$ & $\begin{array}{l}\text { MUCP/FPL/ } \\
\text { PVR }\end{array}$ & $\begin{array}{l}\text {-MUCP } \\
\text { increase }(\approx \\
\left.9.2 \mathrm{cmH}_{2} \mathrm{O}\right) \\
\text {-FPL } \\
\text { increase }(\approx \\
5.6 \mathrm{~mm}) \\
\text {-PVR } \\
\text { decrease }(\approx \\
4.5 \mathrm{ml})\end{array}$ & $\begin{array}{l}\text { 24-h pad } \\
\text { test/ICIQ-QOL } \\
\text { / ICIQ-SF }\end{array}$ & $\begin{array}{l}\text { 8/11 } \\
\text { improvement } \\
\text { 3/11 no } \\
\text { improvement }\end{array}$ & $\begin{array}{l}\text { Mild } \\
\text { subcutaneous } \\
\text { hemorrhage as } \\
\text { complication } \\
\text { of liposuction } \\
(\mathrm{n}=4) \text {. }\end{array}$ & [52] \\
\hline $\begin{array}{l}\text { Autologou } \\
\text { s ADRCs }\end{array}$ & SUI after RP & 6 males & $\begin{array}{l}\text { Periurethral injection: } \\
\text {-Rhabdosphincter ( } 5 \\
\text { and } 7 \text { o'clock positions) } \\
\text {-Submucosal space of } \\
\text { the membranous } \\
\text { urethra ( } 4,6 \text { and } 8 \\
\text { o'clock positions). }\end{array}$ & 3 & $\begin{array}{l}\text { MUCP/ } \\
\text { MIR/ FPL }\end{array}$ & $\begin{array}{l}\text {-MUCP } \\
\text { increase }(\approx \\
19.5 \\
\left.\mathrm{cmH}_{2} \mathrm{O}\right) \\
-\mathrm{MIR} \\
\text { increase }(\approx \\
2.2 \mathrm{~mm}) \\
\text {-FPL n/a }\end{array}$ & $\begin{array}{l}\text { 24-h pad test/ } \\
\text { ICIQ-SF }\end{array}$ & $\begin{array}{l}6 / 6 \\
\text { Improvement }\end{array}$ & $\begin{array}{l}\text { Significant } \\
\text { side effects of } \\
\text { inflammation } \\
\text { were not } \\
\text { observed. }\end{array}$ & [53] \\
\hline
\end{tabular}

Abbreviations: ASCs: Adipose stem cells; ADSCs: Adipose-derived stem cells; CBSC: Cord Blood stem cells; TNCs: Total nucleated cells; RC: Radical cystoprostatectomy with neobladder; TPR: Transurethral prostate resection; DLV: Diary leakage volume; UTI: Urinary tract infection; UTU: Upper tract ultrasonography, URV: urine residual volume; PVR: post voiding residue, SUI: Stress Urinary Incontinence; RP: Radical prostactetomy; UI: Urinary Incontinence; UISS: Urinary inventory stress test; IIQ-7: Incontinence Impact Questionnaire-short form; UDI-6 Urogenital distress inventory-short form; VAS: Visual analogue scale; ICIQ-SF: International Consultation on Incontinence Questionnaire Short-Form ICIQ-UI: International Consultation on Incontinence Questionnaire-Urinary incontinence: ICIQ-QOL: International Consultation on Incontinence Modular Questionnaire-Quality of Life; MUCP: Maximum urethral closure pressure; FPL: Functional profile length; MIR: Magnetic resonance imaging; w/o: without; n/a: not available. 
The results published in the different clinical trials using non-muscle derived stem cells highlighted the capacity of other cell sources to regenerate the damage sphincter. All these cell types meet the requirements for an ideal cell for tissue engineering such as use of autologous cells, accessibility by minimally invasive procedures, providing sufficient quantities of cells, exhibiting potency to regenerate multiple tissues and proliferating quickly in a well-controlled manner. Therefore, these promising results open new doors for the use of tissue engineering in the treatment of SUI patients.

\section{Future directions}

Stem cell therapy has a promising potential to revolutionize the treatment of an elevated number of chronic conditions. Stem cells have the ability to locate and regenerate the injured tissues of the body and to stimulate angiogenesis, anti-inflammatory response, immunomodulation and anti-fibrotic factors production. In the urology field the regenerative therapies have remained at the forefront as new alternative treatments in kidney, urethra, and bladder disorders.

Given the rapid growth in the last years of SUI in the aging population, the application of cell therapy and the regenerative medicine may have profound medical and social implications. A fair amount of preclinical models have been used to study stem cells as treatments for SUI including murine and porcine models [26, 32, 34-35, 47-49]; however much research is still in need before these therapies may be introduced into the routine clinical practice. The overall clinical experience observed in the different clinical trials reviewed indicates that stem cell therapy can be feasible and safely performed and it is efficient if the right cell type is used in suitable patients. Nevertheless, controversial outcomes have been observed in some clinical trials. Cell therapy in human using MDSCs, as well as non-muscle derived stem cells (e.g ADSCs, ASCs, TNCs or CBSCs) showed in some clinical trials only moderate to low clinical effectiveness $[25,56]$. Moreover, a delay in the onset of effect (up to 6-8 months) was observed in some patients [38, 51]. Furthermore, due to ethical and regulatory concerns some of the studies carried out in SUI patients have been retracted in the last years [4, 59-61]. Consequently, we must make an effort in defining the potential perfect patient for cell therapy and also further studies are needed with longer follow-ups, placebo controls and larger numbers of patients in order to clarify the role of stem cell therapy for the treatment of SUI patients.

\section{Abbreviations}

SUI: Stress Urinary Incontinence; UI: Urinary Incontinence; MUI: Mixed Urinary Incontinence; UUI: Urgency Urinary Incontinence; MDSCs: Musclederived stem cells; LPP: Leak Point Pressure; IIQ-7: Incontinence Impact Questionnaire-short form; UDI-6: Urogenital distress inventory-short form; MUF: Maximum urinary flow; PVR: post voiding residue; QOL-q: Quality of Life Questionarie; CLPP: Cough leak-point pressure; VLPP: Valsalva leak point pressure; QOL: Quality of life; RP: Radical prostactetomy; MBC: Maximum bladder capacity; MRU: Maximum residual urine; MDP: Maximum detrusor pressure; MUCP: Maximum urethral closure pressure; MSCs: Mesenchymal stem cells; ADSCs: Adipose derived stem cells; ADRCs: Adipose derived regenerative cells; MIR: Magnetic resonance imaging; ASCs: Adipose stem cells; CBSC: Cord Blood stem cells; TNCs: Total nucleated cells; EPC: Endothelial Progenitor Cells; ISD: intrinsic sphincter deficiency; ICIQ-UI: Incontinence Questionnaire-Urinary incontinence: ICIQ-QOL: Incontinence Modular Questionnaire-Quality of Life.

\section{Acknowledgments}

This work was supported by the Servicio Andaluz de Salud from the Consejería de Salud de la Junta de Andalucía, grant PI 0222-2014, co-founded by Fondo Europeo de Desarrollo Regional (FEDER), European Union.

\section{Competing Interests}

The authors have declared that no competing interest exists.

\section{References}

[1] Norton P, Brubaker L. Urinary incontinence in women. Lancet. 2006; 367:57-67

[2] Levy R, Muller N. Urinary incontinence: economic burden and new choices in pharmaceutical treatment. Adv Ther. 2006; 23:556-73

[3] Wilson L, Brown JS, Shin GP, Luc KO, Subak LL. Annual direct cost of urinary incontinence. Obstet Gynecol. 2001;98:398-406

[4] Lin CS, Lue TF. Stem cell therapy for stress urinary incontinence: a critical review. Stem Cells Dev. 2012; 21:834-43

[5] Gibbs CF, Johnson TM, 2nd, Ouslander JG. Office management of geriatric urinary incontinence. Am J Med. 2007; 120:211-20

[6] Hoyland K, Vasdev N, Abrof A, Boustead G. Post-Radical Prostatectomy Incontinence: Etiology and Prevention. Reviews in Urology. 2014; 16:181-8

[7] Danforth KN, Townsend MK, Lifford K, Curhan GC, Resnick NM, Grodstein F. Risk Factors for Urinary Incontinence among Middle-aged Women. American journal of obstetrics and gynecology. 2006; 194:339-45

[8] Shamliyan TA, Kane RL, Wyman J, Wilt TJ. Systematic review: randomized, controlled trials of nonsurgical treatments for urinary incontinence in women. Ann Intern Med. 2008; 148:459-73

[9] Sweeney DD, Chancellor MB. Treatment of Stress Urinary Incontinence with Duloxetine Hydrochloride. Reviews in Urology. 2005; 7:81-6

[10] Radley SC, Chapple CR, Bryan NP, Clarke DE, Craig DA. Effect of methoxamine on maximum urethral pressure in women with genuine stress incontinence: a placebo-controlled, double-blind crossover study. Neurourol Urodyn. 2001; 20:43-52

[11] Siddiqui ZA, Abboudi H, Crawford R, Shah S. Intraurethral bulking agents for the management of female stress urinary incontinence: a systematic review. Int Urogynecol J. 2017; 21:017-3278 
[12] Matsuoka PK, Locali RF, Pacetta AM, Baracat EC, Haddad JM. The efficacy and safety of urethral injection therapy for urinary incontinence in women: a systematic review. Clinics (Sao Paulo). 2016; 71:94-100

[13] Smaldone MC, Chen ML, Chancellor MB. Stem cell therapy for urethral sphincter regeneration. Minerva Urol Nefrol. 2009; 61:27-40

[14] Ravier E, Fassi-Fehri H, Crouzet S, Gelet A, Abid N, Martin X. Complications after artificial urinary sphincter implantation in patients with or without prior radiotherapy. BJU International. 2015; 115:300-7

[15] Nitti VW. Complications of midurethral slings and their management. Canadian Urological Association Journal. 2012; 6:S120-S2

[16] Hwang IS, Yu JH, Chung JY, Noh CH, Sung LH. One-Year Outcomes of Mid-urethral Sling Procedures for Stress Urinary Incontinence According to Body Mass Index. Korean Journal of Urology. 2012; 53:171-7

[17] Léon P, Chartier-Kastler E, Rouprêt M, Ambrogi V, Mozer P, Phé V. Long-term functional outcomes after artificial urinary sphincter implantation in men with stress urinary incontinence. BJU International. 2015; 115:951-7

[18] Tran C, Damaser MS. The potential role of stem cells in the treatment of urinary incontinence. Ther Adv Urol. 2015; 7:22-40

[19] Kim JH, Lee HJ, Song YS. Treatment of Bladder Dysfunction Using Stem Cell or Tissue Engineering Technique. Korean Journal of Urology. 2014; 55:228-38

[20] Lo B, Parham L. Ethical Issues in Stem Cell Research. Endocrine Reviews. 2009; 30:204-13

[21] Sebe P, Doucet C, Cornu JN, et al. Intrasphincteric injections of autologous muscular cells in women with refractory stress urinary incontinence: a prospective study. Int Urogynecol J. 2011; 22:183-9

[22] Huang YC, Shindel AW, Ning H, et al. Adipose derived stem cells ameliorate hyperlipidemia associated detrusor overactivity in a rat model. J Urol. 2010; 183:1232-40

[23] Carr LK, Steele D, Steele S, et al. 1-year follow-up of autologous muscle-derived stem cell injection pilot study to treat stress urinary incontinence. Int Urogynecol J Pelvic Floor Dysfunct. 2008; 19:881-3

[24] Chermansky CJ, Cannon TW, Torimoto K, et al. A model of intrinsic sphincteric deficiency in the rat: Electrocauterization. Neurourology and Urodynamics. 2004; 23:166-71

[25] Gerullis H, Eimer C, Georgas E, et al. Muscle-derived cells for treatment of iatrogenic sphincter damage and urinary incontinence in men. Scientific World Journal. 2012; 2012:898535

[26] Fu Q, Song XF, Liao GL, Deng CL, Cui L. Myoblasts differentiated from adipose-derived stem cells to treat stress urinary incontinence. Urology. 2010; 75:718-23

[27] Dissaranan C, Cruz MA, Kiedrowski MJ, et al. Rat mesenchymal stem cell secretome promotes elastogenesis and facilitates recovery from simulated childbirth injury. Cell Transplant. 2014; 23:1395-406

[28] Herrera-Imbroda B, Lara MF, Izeta A, Sievert KD, Hart ML. Stress urinary incontinence animal models as a tool to study cell-based regenerative therapies targeting the urethral sphincter. Adv Drug Deliv Rev. 2015; 82-83:106-16

[29] Hart ML, Izeta A, Herrera-Imbroda B, Amend B, Brinchmann JE. Cell Therapy for Stress Urinary Incontinence. Tissue Eng Part B Rev. 2015; 21:365-76

[30] Jankowski RJ, Deasy BM, Huard J. Muscle-derived stem cells. Gene Ther. 2002; 9:642-7

[31] Zhou S, Zhang K, Atala A, et al. Stem Cell Therapy for Treatment of Stress Urinary Incontinence: The Current Status and Challenges. Stem Cells Int. 2016; 2016:7060975

[32] Chermansky CJ, Tarin T, Kwon DD, et al. Intraurethral muscle-derived cell injections increase leak point pressure in a rat model of intrinsic sphincter deficiency. Urology. 2004; 63:780-5

[33] Lee JY, Cannon TW, Pruchnic R, Fraser MO, Huard J, Chancellor MB. The effects of periurethral muscle-derived stem cell injection on leak point pressure in a rat model of stress urinary incontinence. International Urogynecology Journal. 2003; 14:31-7

[34] Kim SO, Na HS, Kwon D, Joo SY, Kim HS, Ahn Y. Bone-marrow-derived mesenchymal stem cell transplantation enhances closing pressure and leak point pressure in a female urinary incontinence rat model. Urol Int. 2011; 86:110-6

[35] Mitterberger M, Pinggera GM, Marksteiner R, et al. Functional and histological changes after myoblast injections in the porcine rhabdosphincter. Eur Urol. 2007; 52:1736-43

[36] Carr LK, Robert M, Kultgen PL, et al. Autologous muscle derived cell therapy for stress urinary incontinence: a prospective, dose ranging study. J Urol. 2013; 189:595-601

[37] Cornu JN, Lizee D, Pinset C, Haab F. Long-term follow-up after regenerative therapy of the urethral sphincter for female stress urinary incontinence. Eur Urol. 2014; 65:256-8

[38] Stangel-Wojcikiewicz K, Jarocha D, Piwowar M, et al. Autologous muscle-derived cells for the treatment of female stress urinary incontinence: a 2-year follow-up of a Polish investigation. Neurourol Urodyn. 2014; 33:324-30

[39] Stangel-Wojcikiewicz K, Piwowar M, Jach R, Majka M, Basta A. Quality of life assessment in female patients 2 and 4 years after muscle-derived cell transplants for stress urinary incontinence treatment. Ginekol Pol. 2016; 87:183-9

[40] Blaganje M, Lukanovic A. Intrasphincteric autologous myoblast injections with electrical stimulation for stress urinary incontinence. Int J Gynaecol Obstet. 2012; 117:164-7
[41] Peters KM, Dmochowski RR, Carr LK, et al Autologous muscle derived cells for treatment of stress urinary incontinence in women. J Urol. 2014;192:469-76

[42] Mitterberger M, Marksteiner R, Margreiter E, et al. Myoblast and fibroblast therapy for post-prostatectomy urinary incontinence: 1-year followup of 63 patients. J Urol. 2008; 179:226-31

[43] Bareja A, Billin AN. Satellite cell therapy - from mice to men. Skeletal Muscle. 2013; 3:2

[44] Zuk PA, Zhu M, Ashjian P, et al. Human adipose tissue is a source of multipotent stem cells. Mol Biol Cell. 2002; 13:4279-95

[45] Zuk PA, Zhu M, Mizuno H, et al. Multilineage cells from human adipose tissue: implications for cell-based therapies. Tissue Eng. 2001; 7:211-28

[46] Rehman J, Traktuev D, Li J, et al. Secretion of angiogenic and antiapoptotic factors by human adipose stromal cells. Circulation. 2004; 109:1292-8

[47] Zhao W, Zhang C, Jin C, et al. Periurethral injection of autologous adipose-derived stem cells with controlled-release nerve growth factor for the treatment of stress urinary incontinence in a rat model. Eur Urol. 2011; 59:155-63

[48] Li G-Y, Zhou F, Gong Y-Q, et al. Activation of VEGF and ERK1/2 and Improvement of Urethral Function by Adipose-derived Stem Cells in a Rat Stress Urinary Incontinence Model. Urology. 2012; 80:953.e1-.e8

[49] Obinata D, Matsumoto T, Ikado Y, et al. Transplantation of mature adipocyte-derived dedifferentiated fat (DFAT) cells improves urethral sphincter contractility in a rat model. Int J Urol. 2011; 18:827-34

[50] Lin C-S, Lue TF. Stem Cell Therapy for Stress Urinary Incontinence: A Critical Review. Stem Cells and Development. 2012; 21:834-43

[51] Yamamoto T, Gotoh M, Kato M, et al. Periurethral injection of autologous adipose-derived regenerative cells for the treatment of male stress urinary incontinence: Report of three initial cases. Int J Urol. 2012; 19:652-9

[52] Gotoh M, Yamamoto T, Kato M, et al. Regenerative treatment of male stress urinary incontinence by periurethral injection of autologous adipose-derived regenerative cells: 1-year outcomes in 11 patients. Int J Urol. 2014; 21:294-300

[53] Choi JY, Kim TH, Yang JD, Suh JS, Kwon TG. Adipose-Derived Regenerative Cell Injection Therapy for Postprostatectomy Incontinence: A Phase I Clinical Study. Yonsei Med J. 2016; 57:1152-8

[54] Lin K, Matsubara Y, Masuda $Y$, et al. Characterization of adipose tissue-derived cells isolated with the Celution system. Cytotherapy. 2008; 10:417-26

[55] Kuismanen K, Sartoneva R, Haimi S, et al. Autologous adipose stem cells in treatment of female stress urinary incontinence: results of a pilot study. Stem Cells Transl Med. 2014; 3:936-41

[56] Lee CN, Jang JB, Kim JY, Koh C, Baek JY, Lee KJ. Human cord blood stem cell therapy for treatment of stress urinary incontinence. J Korean Med Sci. 2010; 25:813-6

[57] Borrione P, Gianfrancesco AD, Pereira MT, Pigozzi F. Platelet-rich plasma in muscle healing. Am J Phys Med Rehabil. 2010; 89:854-61

[58] Shirvan MK, Alamdari DH, Mahboub MD, Ghanadi A, Rahimi HR, Seifalian AM. A novel cell therapy for stress urinary incontinence, short-term outcome. Neurourol Urodyn. 2013; 32:377-82

[59] Strasser H, Marksteiner R, Margreiter E, et al. Autologous myoblasts and fibroblasts versus collagen for treatment of stress urinary incontinence in women: a randomised controlled trial. Lancet. 2007; 369:2179-86

[60] Yamamoto T, Gotoh M, Hattori R, et al. Periurethral injection of autologous adipose-derived stem cells for the treatment of stress urinary incontinence in patients undergoing radical prostatectomy: report of two initial cases. Int J Urol. 2010; 17:75-82

[61] Strasser H, Marksteiner R, Margreiter E, et al. Transurethral ultrasonography-guided injection of adult autologous stem cells versus transurethral endoscopic injection of collagen in treatment of urinary incontinence. World J Urol. 2007; 25:385-92 